\title{
The effects of anaesthesia on the developing brain: a
}

\section{summary of the clinical evidence [version 1; peer review: 2}

\section{approved]}

\author{
Clara KY Yu1 ${ }^{1}$ Vivian Man Ying Yuen1, Gordon TC Wong2, Michael G Irwin² \\ ${ }^{1}$ Department of Anaesthesiology, Queen Mary Hospital, Hong Kong \\ 2Department of Anaesthesiology, University of Hong Kong, Hong Kong
}

V1 First published: 02 Aug 2013, 2:166

https://doi.org/10.12688/f1000research.2-166.v1

Latest published: 20 Aug 2013, 2:166

https://doi.org/10.12688/f1000research.2-166.v2

\section{Abstract}

Introduction: There is data amassing in the literature regarding the potentially adverse effects of anaesthesia exposure on the developing human brain. The purpose of this article is to summarise current relevant data from clinical studies in this area.

Methods: Articles from journals written in English were searched for using PubMed, Ovid and Medline. Keywords used included: brain (newborn, infant, child and neonate), neurodegeneration, apoptosis, toxicity, neurocognitive impairment (developmental impairment and learning disorders) and anaesthesia (intravenous, inhalational and sedation).

Results: From the initial search, 23 articles were identified as potentially relevant, with publication dates spanning from 1978 to 2012. Twelve studies were deemed irrelevant to the research questions. The results of neurocognitive assessment from eight of the remaining eleven studies had showed some differences in the performances of children exposed to anaesthesia. The control population in these studies was highly variable. The age at which the subjects were exposed to anaesthesia ranged from prenatal to 4 years in the majority of studies with one including children aged up to 12 years when exposed.

Discussion: Although there is clinical data suggesting a possible detrimental effect, the evidence is best considered preliminary and inconclusive at this stage. Many of the outcome measures were lacking in specificity and standardization in most cases. Parents should be counselled to not avoid necessary invasive procedures for fear of a currently ill-defined risk. However, deferral of elective procedures beyond the first few years of life should be contemplated.

Keywords

Anaesthesia, brain, neurodegeneration, toxicity

\section{Open Peer Review \\ Approval Status \\ $\checkmark$ \\ 1 \\ 2 \\ version 2 \\ (update) \\ 20 Aug 2013 \\ version 1 \\ 02 Aug 2013

view \\ 1. Caleb Ing, Columbia University Medical Centre, New York, USA \\ 2. Igor Luginbuehl, University of Toronto, Toronto, Canada \\ Any reports and responses or comments on the article can be found at the end of the article.}


Corresponding author: Gordon TC Wong (gordon@hku.hk)

Competing interests: No competing interests were disclosed.

Grant information: The author(s) declared that no grants were involved in supporting this work.

Copyright: ( 2013 Yu CK et al. This is an open access article distributed under the terms of the Creative Commons Attribution License, which permits unrestricted use, distribution, and reproduction in any medium, provided the original work is properly cited. Data associated with the article are available under the terms of the Creative Commons Zero "No rights reserved" data waiver (CC0 1.0 Public domain dedication).

How to cite this article: Yu CK, Yuen VMY, Wong GT and Irwin MG. The effects of anaesthesia on the developing brain: a summary of the clinical evidence [version 1; peer review: 2 approved] F1000Research 2013, 2:166 https://doi.org/10.12688/f1000research.2166.v1

First published: 02 Aug 2013, 2:166 https://doi.org/10.12688/f1000research.2-166.v1 


\section{Introduction}

Advances in perioperative care and imaging have resulted in more neonates, infants and children undergoing procedures requiring anaesthesia. General anaesthesia is a incompletely understood, complex pharmacological response produced by a heterogeneous class of drugs involving mechanisms on specific neuronal networks in different regions of the central nervous system. It is well known that the use of a balanced anaesthetic technique is beneficial in decreasing the neuroendocrine and metabolic stress response to surgery and altering pain processing ${ }^{1-4}$. However, increasing data from animal studies in the last decade has shown that general anaesthesia may also trigger apoptosis in the developing brain and suggest anaesthetic interactions with neurodegenerative mechanisms, including those linked to the onset and progression of Alzheimer's disease ${ }^{5,6}$. Naturally this has raised much concern regarding the safety of general anaesthesia in infants and young children. The developing brain differs from the adult brain in several different ways, which may provide a physiological basis for any enhanced vulnerability to anaesthetics. For example, the number of neurones formed in early development is significantly greater than in adult mammals, before synapses are pruned to establish behaviourally relevant connections between neurones. Apoptosis is responsible for eliminating 50-70\% of developing neurones under normal circumstances and general anaesthesia-triggered apoptosis may disrupt this normal pattern of neural pruning ${ }^{7}$. The purpose of this article is to summarise the current literature concerning the effects of anaesthesia on the developing brain and to evaluated whether the available animal data can be translated to a clinical setting. The aim is to provide up-to-date information to non-anaesthetists who may need to counsel parents in the preoperative setting.

\section{Method}

Search engines used included PubMed, Ovid Medline and Embase, which were accessed in March 2013. Keywords used included: brain (newborn, infant, child or neonate), neurodegeneration, apoptosis, toxicity, neurocognitive impairment (developmental impairment or learning disorders) and an(a)esthesia (intravenous, inhalational and sedation). These were used in combination such that terms related to anaesthesia and brain was used together and were paired with the remaining terms in turn. Exclusion criteria were animal studies investigating anaesthesia-induced brain structural or behavioural abnormalities and articles published in non-English language journals.

\section{Results}

A total of 23 articles were identified using the above search methods. Of these 12 were deemed irrelevant to our research question and were excluded in our discussion (Table 1). Eight of these studies focused mainly on surgical diseases, their management and neurological outcome. The study groups were sick neonates and a majority had very low birth-weights, which adds to the multiple confounding factors. These studies were not designed to investigate anaesthetic exposure and its potential neurotoxicity. The anaesthetic technique and agent used were not specified and subsequent surgery requiring anaesthesia is unknown, hence they are excluded in our review. Three of the 12 studies were performed in the third trimester of pregnancy and one during the perinatal period. Because outcome measure of behaviour alterations was performed in the first few days after birth, any positive finding may be subtle and not relevant in the long-term outcome. Hence these studies were also excluded. Therefore, only 11 relevant publications on neurodevelopmental risk and anaesthesia exposure in early childhood were identified ${ }^{7-16}$, all of which were retrospective in nature (Table 2). Owing to the nature of the study question, the vast majority of the studies were either cohort or case control studies. The respective control population in these studies was, however, highly variable. In all but three studies, the results of neurocognitive assessment had showed some abnormalities in the performance of children exposed to anaesthesia. The age at which the subjects were exposed to anaesthesia ranged from prenatal to 3 years in the majority of studies with one including children aged up to 12 years when exposed.

A group at the Mayo Clinic in Rochester was responsible for four of the included studies, using a birth cohort of children born in Rochester, Minnesota, USA, between 1976 and $1982^{13-16}$. In one of the investigations ${ }^{13}, 593$ children with anaesthetic exposure before the age of 4 were compared with 4764 children with no anaesthetic exposure. Children receiving two, three or more anaesthetics were respectively 1.59 or 2.6 times more likely to have subsequent learning disabilities. Using the data from the same cohort, 350 children with anaesthetic exposure were compared with 5007 children with no anaesthetic exposure before the age of 2 years ${ }^{16}$. Children who had two or more exposures were 1.95 times more likely to be diagnosed with Attention Deficit Hyperactive Disorder (ADHD) than the unexposed children. From the same cohort in a matched design study, 350 children who had anaesthetic exposure before the age of 2 for were compared to 700 unexposed matched controls on the basis of known risk factors for learning disability ${ }^{14}$. Again children who had two or more anaesthetic exposures, but not single exposure, had an increased risk of subsequent learning disability (hazard ratio 2.12). The last study from the same cohort revealed that a single perinatal exposure to general anaesthesia during delivery by Caesarean section was not associated with an increased risk of learning disability ${ }^{15}$.

Using another national registry, investigators at Odense University in Denmark identified a cohort of 2689 children born between 1986 and 1990 that had a hernia repair before one year of age ${ }^{12}$. These children were compared with a randomly selected, age matched population consisting of 14575 children. The average test scores at ninth grade and test score non-attainment rate were used as marker for learning disability. After adjusting for confounding factors, no significant differences in either parameter between the two groups were found.

Investigators at Columbia University used the New York State Medicaid registry to identify a birth cohort of children who had surgery before the age of 3 years ${ }^{7,9}$. Medicaid is a health insurance program provided by US government covering approximately $25 \%$ of all children in the USA. In the first study 383 children whose insurance codes indicated surgery for inguinal hernia before age 3 years were identified ${ }^{9}$. These children were compared to a cohort of 5050 matched controls. Insurance codes were used to identify children with behavioural or development disorders. After controlling for potential confounders, children who had hernia repair before 
Table 1. List of retrieved but excluded studies.

\begin{tabular}{|c|c|c|c|c|c|c|}
\hline Reference & $\begin{array}{l}\text { Year of } \\
\text { birth } \\
\text { cohort }\end{array}$ & Study group & Control group & $\begin{array}{l}\text { Age during } \\
\text { exposure }\end{array}$ & $\begin{array}{l}\text { Age during } \\
\text { neurological } \\
\text { assessment }\end{array}$ & $\begin{array}{l}\text { Neurological sequelae in the } \\
\text { study group }\end{array}$ \\
\hline $\begin{array}{l}\text { Kabra et al. } \\
2007\end{array}$ & 1996-1998 & $\begin{array}{l}\text { PDA ligation } \\
(\mathrm{N}=95)\end{array}$ & $\begin{array}{l}\text { Indomethacin } \\
\text { treatment }(\mathrm{N}=245)\end{array}$ & $\begin{array}{l}84 \% \text { neonatal } \\
\text { (25-29wk } \\
\text { PCA), ELBW }\end{array}$ & $18 \mathrm{mo}$ & $\begin{array}{l}\text { Increase in cerebral palsy, } \\
\text { cognitive delay, hearing loss, } \\
\text { bilateral blindness }\end{array}$ \\
\hline $\begin{array}{l}\text { Hintz et al. } \\
2005\end{array}$ & 1995-1998 & $\begin{array}{l}\text { Laparotomy } \\
(\mathrm{N}=124)\end{array}$ & $\begin{array}{l}\text { Peritoneal drain } \\
\text { placement } \\
(\mathrm{N}=121)\end{array}$ & $\begin{array}{l}\text { Neonatal, } \\
\text { ELBW }\end{array}$ & 18-22mo & $\begin{array}{l}\text { Higher frequency of cerebral } \\
\text { palsy, lower Bayley Scales } \\
\text { of Infant Development; no } \\
\text { difference between medically } \\
\text { treated patients with or without } \\
\text { NEC }\end{array}$ \\
\hline $\begin{array}{l}\text { Tobiansky et al. } \\
1995\end{array}$ & & $\begin{array}{l}\text { NEC requiring } \\
\text { laparotomy } \\
(\mathrm{N}=20)\end{array}$ & $\begin{array}{l}\text { No NEC or } \\
\text { NEC managed } \\
\text { medically }(\mathrm{N}=40)\end{array}$ & $\begin{array}{l}\text { 26-27wk } \\
\text { PCA, VLBW }\end{array}$ & $\begin{array}{l}12 \mathrm{mo}, 3 y r, \text { and } \\
5 y r \text { PCA }\end{array}$ & $\begin{array}{l}\text { Higher incidence of } \\
\text { neurodevelopmental impairment }\end{array}$ \\
\hline $\begin{array}{l}\text { Blakely et al. } \\
2006\end{array}$ & 2001-2002 & $\begin{array}{l}\text { Laparotomy } \\
(\mathrm{N}=76)\end{array}$ & $\begin{array}{l}\text { Peritoneal drain } \\
\text { placement }(\mathrm{N}=80)\end{array}$ & $\begin{array}{l}\text { 29wk PCA, } \\
\text { ELBW }\end{array}$ & $\begin{array}{l}18-22 \text { mo post } \\
\text { term }\end{array}$ & $\begin{array}{l}\text { Less neurodevelopmental } \\
\text { impairment and lower mortality }\end{array}$ \\
\hline $\begin{array}{l}\text { Chacko et al. } \\
1999\end{array}$ & 1990-1993 & $\begin{array}{l}\text { NEC requiring } \\
\text { laparotomy } \\
(\mathrm{N}=10)\end{array}$ & $\begin{array}{l}\text { Gestational age-, } \\
\text { birth weight } \\
\text { matched controls } \\
(\mathrm{N}=20)\end{array}$ & $\begin{array}{l}\text { 26wk PCA, } \\
\text { ELBW }\end{array}$ & 5 and $7 y r$ & $\begin{array}{l}\text { Infants with NEC requiring } \\
\text { laparotomy had increased risk of } \\
\text { neurodevelopmental problems }\end{array}$ \\
\hline $\begin{array}{l}\text { Simon et al. } \\
1993\end{array}$ & & $\begin{array}{l}\text { NEC requiring } \\
\text { laparotomy }(\mathrm{N}=6)\end{array}$ & $\begin{array}{l}\text { NEC managed } \\
\text { medically }(\mathrm{N}=12)\end{array}$ & $\begin{array}{l}\text { Neonatal, } \\
\text { VLBW }\end{array}$ & $\begin{array}{l}15 \mathrm{mo} \text { post } \\
\text { term, } 24 \mathrm{mo}\end{array}$ & $\begin{array}{l}\text { Higher prevalence of motor } \\
\text { delays early after surgery; no } \\
\text { difference detected at } 2 y r \text { of age }\end{array}$ \\
\hline $\begin{array}{l}\text { Miller et al. } \\
1995\end{array}$ & 1987-1989 & $\begin{array}{l}\text { Open heart } \\
\text { surgery }(N=91)\end{array}$ & None & Neonatal & $>2 y r$ & $\begin{array}{l}\text { Cerebral palsy in } 22 \% \text {, mean } \\
\text { IQ } 90 \text {, but highly dependent on } \\
\text { type of congenital heart disease }\end{array}$ \\
\hline Karl et al. 2004 & 1988-1994 & $\begin{array}{l}\text { ASO with limited } \\
\text { DHCA }(N=74)\end{array}$ & $\begin{array}{l}\text { Best friend' control } \\
\text { group or general } \\
\text { population }(\mathrm{N}=74)\end{array}$ & $\begin{array}{l}\text { 0-118 months } \\
\text { (median 9) }\end{array}$ & $9.1+/-2.9 y r$ & $\begin{array}{l}\text { Lower IQ and higher prevalence } \\
\text { of behavioural, language } \\
\text { expression and comprehension } \\
\text { problems than control }\end{array}$ \\
\hline Eishima 1992 & & $\begin{array}{l}\text { Intrauterine } \\
\text { exposure to } \\
\text { nitrous oxide } \\
(\mathrm{N}=159)\end{array}$ & $\begin{array}{l}\text { No intrauterine } \\
\text { exposure }\end{array}$ & $\begin{array}{l}\text { Prenatal, third } \\
\text { trimester }\end{array}$ & $5 d$ postnatal & $\begin{array}{l}\text { Weaker habituation to sound, } \\
\text { stronger muscular tension and } \\
\text { resistance to cuddle, fewer } \\
\text { smiles }\end{array}$ \\
\hline Blair et al. 1984 & & $\begin{array}{l}\text { General or local } \\
\text { anaesthetics } \\
(\mathrm{N}=9)\end{array}$ & $\begin{array}{l}\text { No anaesthetic } \\
\text { exposure }(\mathrm{N}=30)\end{array}$ & $\begin{array}{l}\text { Prenatal: } \\
\text { first to third } \\
\text { trimester }\end{array}$ & $\begin{array}{l}0.8-6 d \\
\text { postnatally }\end{array}$ & $\begin{array}{l}\text { Prolongation of visual-pattern } \\
\text { preference }\end{array}$ \\
\hline $\begin{array}{l}\text { Hollenback } \\
\text { et al. } 1986\end{array}$ & & $\begin{array}{l}\text { General or local } \\
\text { anaesthetic }(\mathrm{N}=7)\end{array}$ & $\begin{array}{l}\text { No anaesthetic } \\
\text { exposure }(\mathrm{N}=7)\end{array}$ & $\begin{array}{l}\text { Prenatal: } \\
\text { first to third } \\
\text { trimester }\end{array}$ & $4+/-0.008 y r$ & Lower IQ scores \\
\hline Hollmen 1978 & & $\begin{array}{l}\text { Thiopental, } \\
\text { nitrous oxide } \\
\text { for general } \\
\text { anaesthesia } \\
(\mathrm{N}=15)\end{array}$ & $\begin{array}{l}\text { Lignocaine } 1.5 \% \\
\text { for epidural } \\
\text { analgesia }(\mathrm{N}=15)\end{array}$ & $\begin{array}{l}\text { Perinatal for } \\
\text { caesarean } \\
\text { section }\end{array}$ & $1-7 d$ & $\begin{array}{l}\text { Abnormal neurological activity } \\
\text { for up to } 7 d \text { in } 47 \% \text { regardless of } \\
\text { group assignment }\end{array}$ \\
\hline
\end{tabular}

3 years of age were more than twice as likely as controls to be subsequently diagnosed with developmental or behavioural disorder. Using the same Medicaid registry, a birth cohort of 10450 siblings was identified by the same group of investigators ${ }^{7}$. Three hundred and four children whose insurance codes indicated surgical procedures before the age of 3 years were compared to 10146 children who had no surgery before the age of 3 . Similarly insurance codes were used to identify children with behavioural or development disorders. Children who had surgical exposure before the 3 years of age were 1.6 times more likely to have a subsequent behavioural or development disorder. This same group of investigators also used the Western Australian Pregnancy Cohort of 2680 children born from 1989-1992 to identify 321 children who had surgical procedures before age of 3 years ${ }^{10}$. Learning ability was assessed by more sensitive and specific neuropsychological tests. These tests include the Symbol Digit Modality Test and Raven's Colored Progressive Matrices for assessment of cognition, the MaCarron Assessment of Neuromuscular Development for assessment of fine and gross motor control, the Clinical Evaluation of Language Fundamentals for assessment of various aspects of language ability. The Child Behavior Checklist (CBCL) was also used for assessment of behavioural problems. Children with single or multiple anaesthesia exposure were shown to have an increased risk of language and abstract reasoning deficits, but there was no association with 

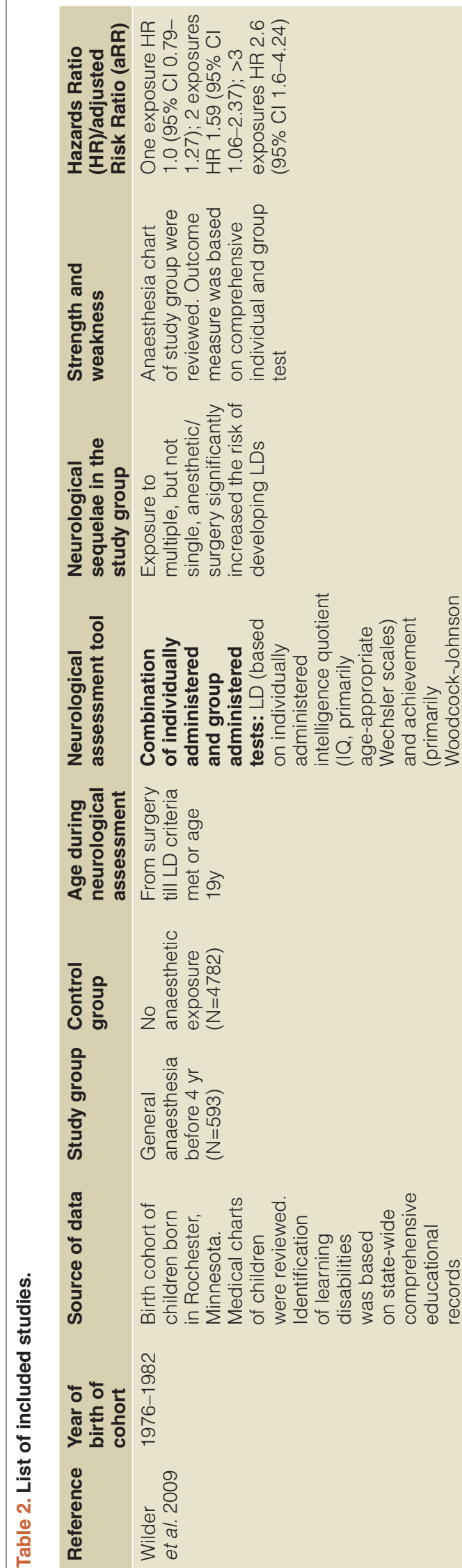
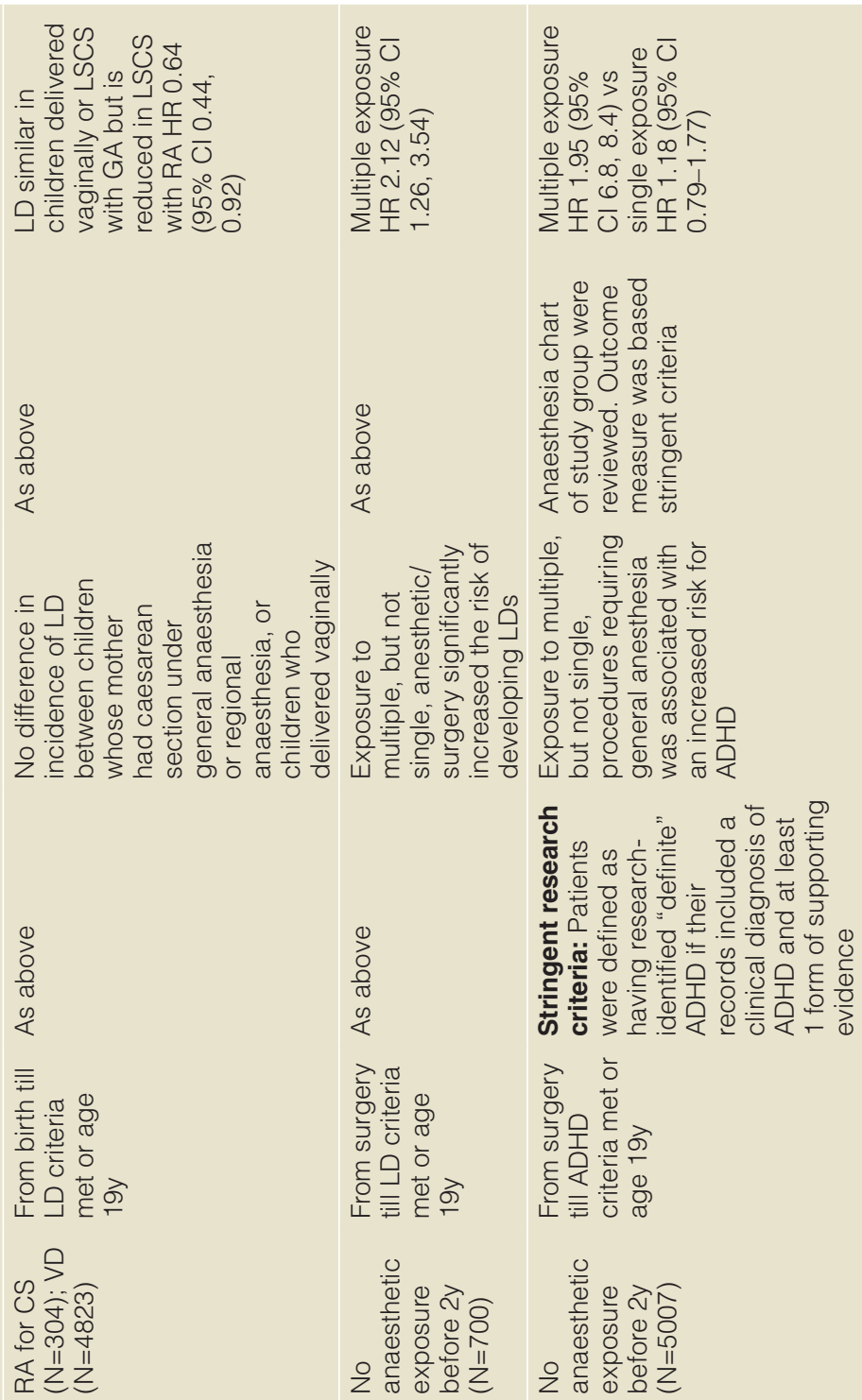

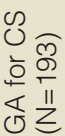
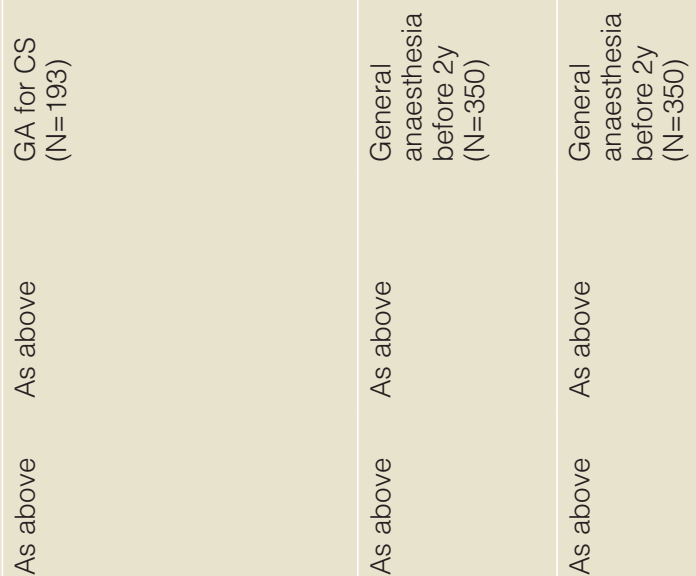

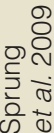

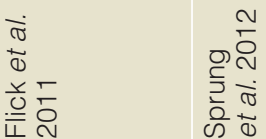




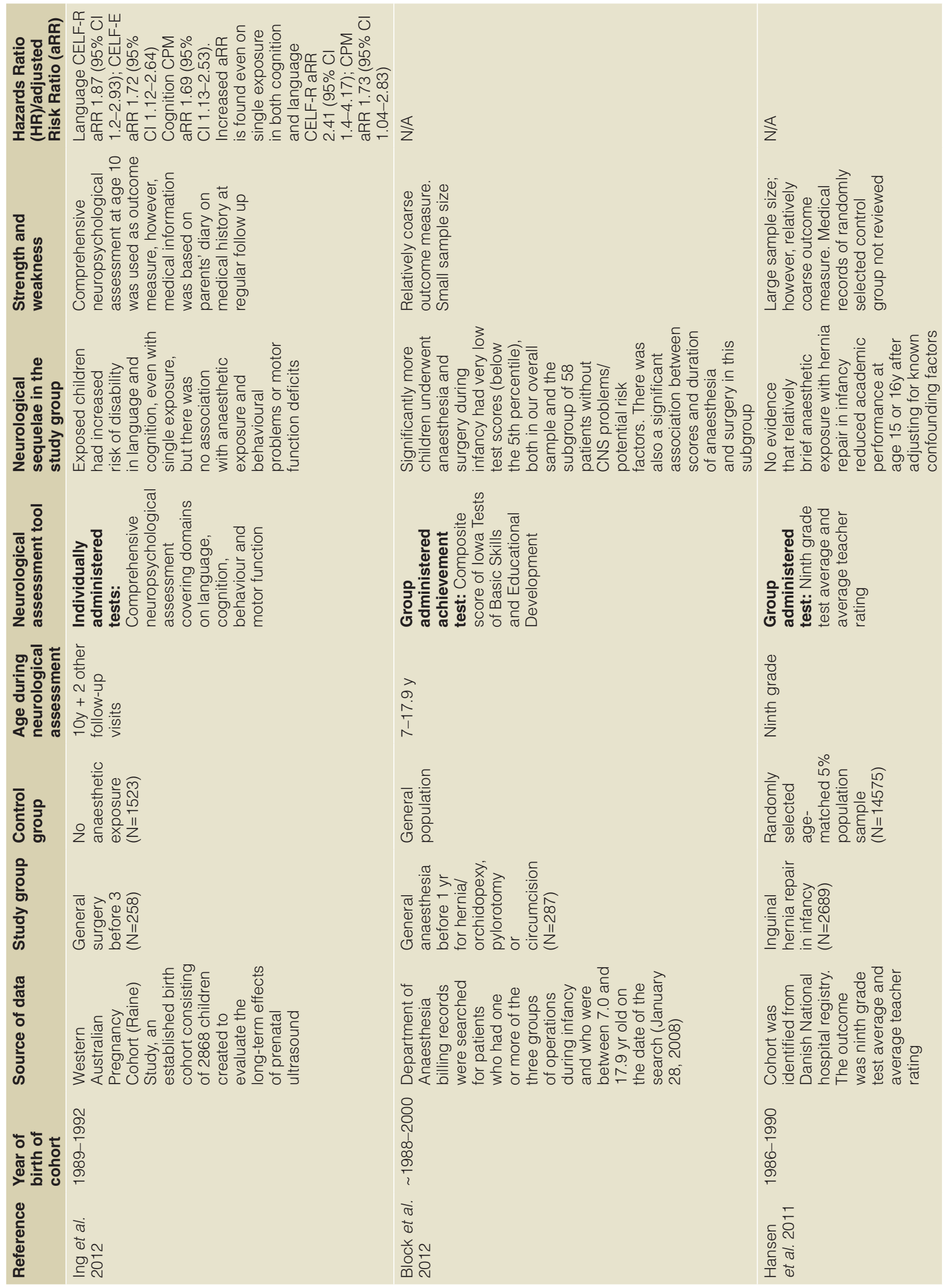




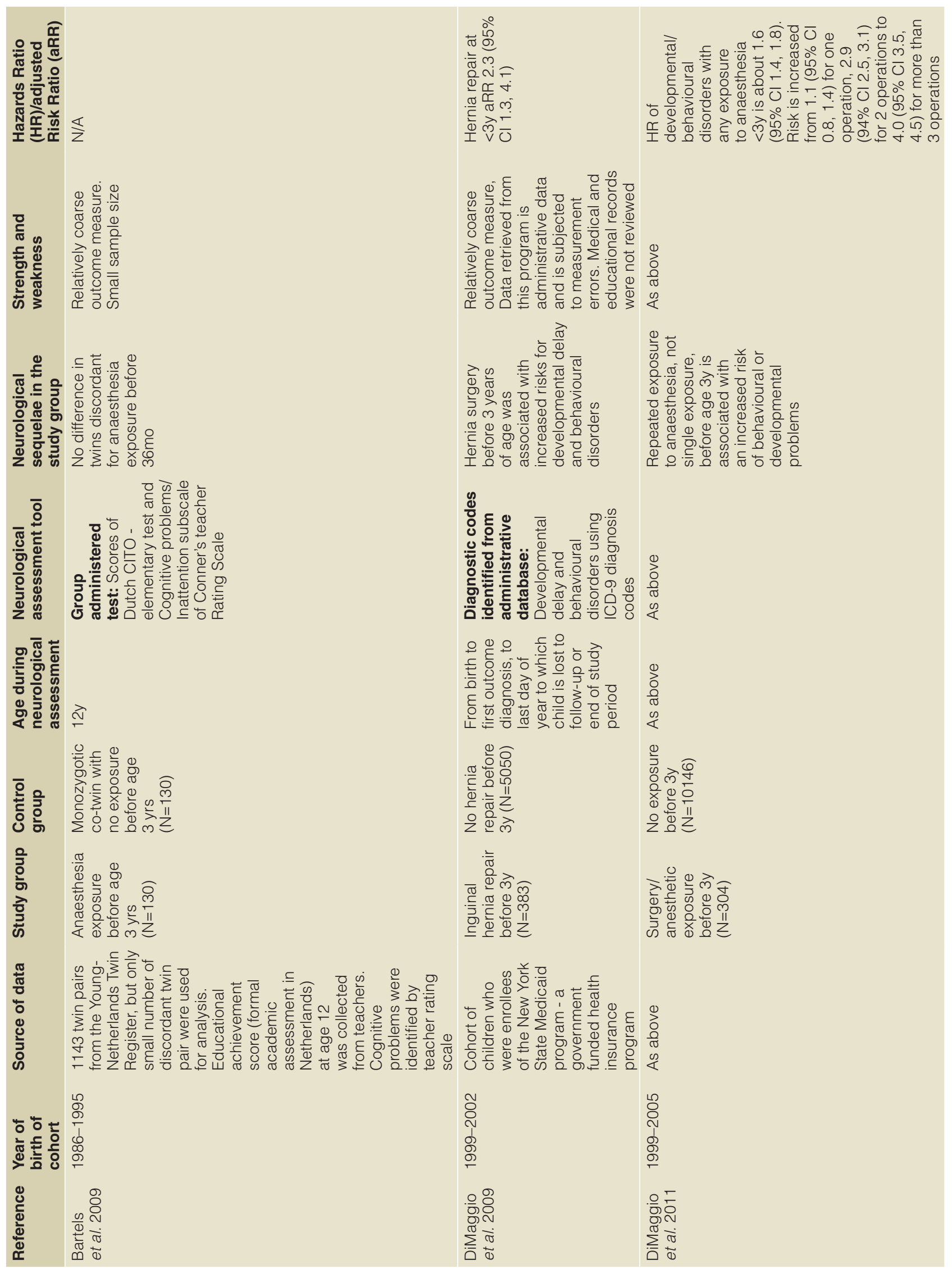




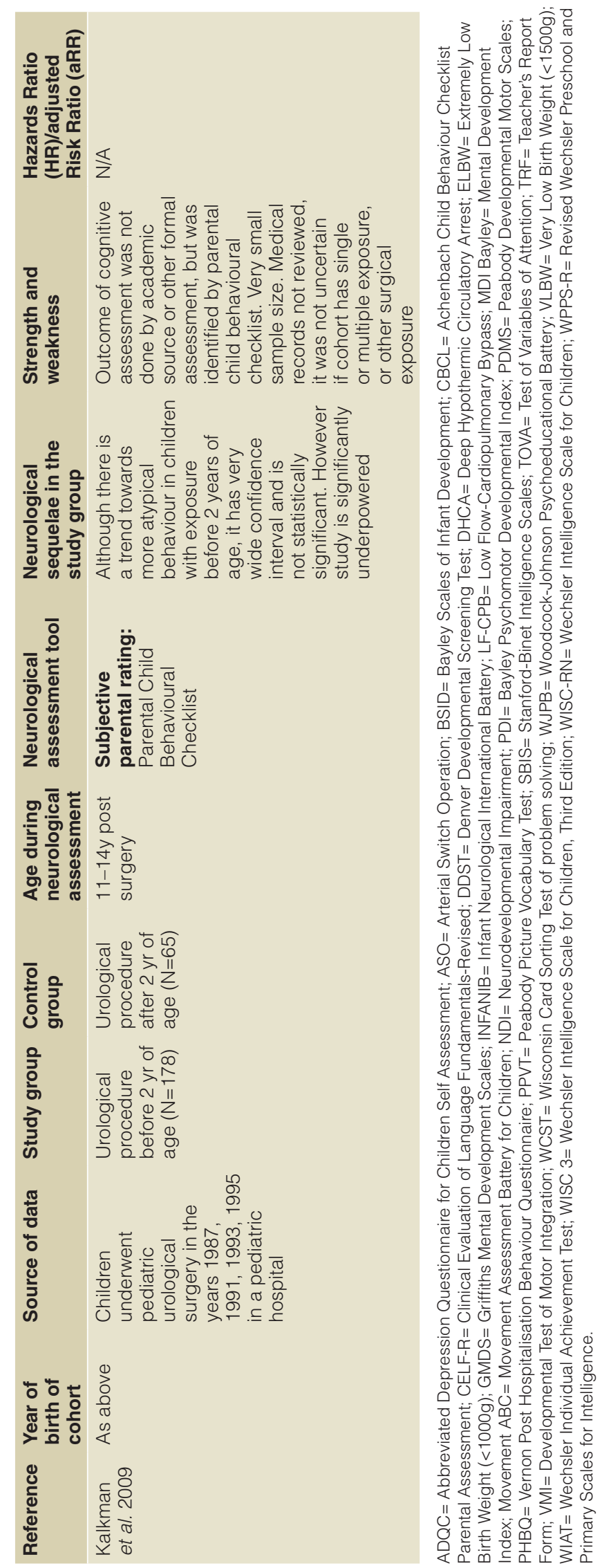


anaesthesia exposure and behavioural or motor problems. The adjusted risk ratio (aRR) was 1.87 [95\% CI 1.2-2.93] for receptive language, 1.72 [95\% CI 1.12-2.64] for expressive language, 2.11 [95\% CI 1.42-3.14] for total language, and 1.69 [95\% CI 1.13-2.53] for abstract reasoning, a domain of the cognitive test.

Investigators at University Medical Centre Utrecht in Netherlands identified 314 children who had urological procedures under general anaesthesia before the age of 6 years $^{8}$. Neurobehavioral development was assessed using Child Behaviour Checklist (CBCL) returned by parents. This study revealed no association with behavioural disturbances and anaesthesia exposure. Another study from the Netherlands (Vrije Universiteit Amsterdam) attempted to explore causality of anaesthesia exposure and learning related outcomes by using a monozygotic concordant-discordant design ${ }^{11}$. The researchers identified 1143 monozygotic twin pairs from the Netherlands Twin Registry. Data on anaesthetic exposure and learning outcomes was based on parental reports and standardized test scores respectively. The authors revealed that children from this cohort who were exposed to anaesthesia before the age of 3 years had significantly lower educational achievement scores and more cognitive problems than the unexposed children. However the unexposed monozygotic twins did not differ from the exposed co-twin.

\section{Discussion}

Clinical observations dating as far back as 60 years have shown an association between exposure to anaesthesia in children and central nervous system dysfunction ${ }^{17}$. Numerous animal studies on rodents and even non-human primates have since been performed to investigate why this may occur ${ }^{18,19}$. Consistently it has been shown that exposure of the developing mammalian brain to most general anaesthetic drugs causes some degree of neuronal apoptosis and neurodegeneration during critical developmental periods ${ }^{5}$. General anaesthetics are powerful modulators of neurotransmission via a variety of ligand-gated ion channels. The drugs vary in their pharmacodynamic effects and receptor interaction so, to some extent, it is difficult to generalise but they mostly potentiate the gamma-amino butyric acid (GABA) receptor complex and/or inhibit glutamatergic neurotransmission principally through blockade of the N-methyl D-aspartate (NMDA) receptor (Table 3$)^{20}$. Both of these neurotransmitter systems are central in determining the excitation/inhibition activity balance underlying experience-dependent sculpting of developing neural networks during the sensitive time of the neuronal "growth spurt" 21 . This critical period coincides with intense synaptogenesis in most cortical regions. In humans this period of synaptogenesis occurs between the third trimester of pregnancy and first few years of postnatal life; the most marked increase in synapse number occurring between birth and six months of age $\mathrm{e}^{22}$. In humans, there are significant regional differences in the timing of the neuronal growth spurt. The earliest is the primary sensorimotor cortex, which occurs around birth, subsequently the parietal and temporal region (important in language and spatial attention) around 9 months and lastly the prefrontal cortex at 2-3 years ${ }^{23}$. During normal development, neurons are produced in excess by as much as $50-70 \%$ and subsequent neuronal pruning is essential for normal brain structure and function ${ }^{7,24}$. The mechanism of anaesthesiainduced cell death is not fully understood. Hence it is uncertain whether anaesthesia-induced apoptosis occurs in cells that are not meant to die i.e. pathological apoptosis, or whether it accelerates the death of cells that are meant to die at a later time i.e. premature physiological apoptosis.

Recent clinical studies may lead one to think this is a significant clinical issue for children undergoing surgery but a closer look at the data however, will reveal that the evidence is far from conclusive. While eight studies revealed a positive association between anaesthetic exposure and neurodevelopmental risk, the other two studies revealed the opposite. However, as studies relevant to this question are, to date, retrospective in nature, they only allowed identification of an association without establishing causality. Although there were large number of emigrates in the Rochester cohort, it did contain more than 5000 children. Complete medical and anaesthetic records were reviewed. Data collected included the type of surgery, type of anaesthetic agents, and number of anaesthetic exposures and duration of anaesthesia. Learning disability was assessed using only educational records. Consistently these studies revealed that single anaesthetic exposure during perinatal period $^{15}$ or before age of 4 years ${ }^{13,14,16}$ was not associated with increased risk of learning disabilities or ADHD behaviour. Multiple exposures however were associated with significantly increased risk for learning disabilities and ADHD disorder and this may signify a dose-response relationship with a progressively increasing risk following two or more operations. Similarly data from the Danish Cohort may indicate that a single brief anaesthetic exposure is not associated with an increased risk of learning disability. The authors using the Western Australia cohort suggested that association between anaesthesia and neurodevelopmental outcome may be confined to specific domains (language and cognition) and this investigation may help to guide future studies.

In four of the investigations where a large cohort of children was identified $^{7,9,10,12}$, information on surgical exposure and behavioural and development diagnosis were based solely on the administrative data of government funded health insurance program or parent questionnaires. Medical and anaesthetic or educational records were not reviewed and therefore misclassification is possible and therefore results drawn from these data are subjected to measurement error. Moreover the children from the Medicaid registry could be children with disadvantaged background and these results may not be generalized to other population groups. Nevertheless some of the imprecision should only lead to an

Table 3. Putative mechanism of sedatives and general anaesthetics on gamma-aminobutyric acid (GABA ${ }_{A}$ ), type $A$; and N-methyl D-aspartate (NMDA) receptors.

$\begin{array}{lll}\text { Drug } & \text { GABA }_{\mathbf{A}} \text { agonist } & \text { NMDA antagonist } \\ \text { Benzodiazepines } & +++ & - \\ \text { Ketamine } & + & +++ \\ \text { Propofol } & ++ & + \\ \text { Nitrous oxide } & + & +++ \\ \text { Isoflurane } & +++ & + \\ \text { Sevoflurane } & +++ & + \\ \text { "-" = no known effect; "+" } & \text { weak effect; ++ strong effect; +++ very strong } \\ \text { effect. } & \end{array}$


under-estimation of true association. In the study by Kalkman et al. ${ }^{8}$ the authors commented that this study may be underpowered to reveal any significant differences. Moreover the CBCL may be an insensitive tool to detect neurodevelopment disability. This result is consistent with the finding from investigators at Columbia University as they have shown anaesthetic exposure is not associated with behavioural or motor disabilities ${ }^{10}$.

In the study involving twins ${ }^{11}$, the authors concluded that anaesthesia exposure does not cause later learning-related disability. Only a small number of twin pairs were discordant for surgical exposure (130 pairs) and an even smaller numbers of twin pairs had an educational achievement score (110) and a cognitive problem scale (56) available ${ }^{25}$. Therefore the lack of difference in scores may be secondary to inadequate sample size. Moreover the number of anaesthetic exposures in this cohort was not stated and this could potentially affect the outcome of interest.

In summary the available data from various studies including large numbers of children points to a possible association between anaesthetic exposure in early childhood and learning disability. Moreover a dose-response effect may be present. However one must be cautious with the conclusions drawn from retrospective studies. Association between early anaesthesia exposure and subsequent learning disability does not indicate anaesthesia neurotoxicity. There are many known and unknown confounding factors. Known co-existing medical or surgical diseases and disruption to learning due to repeated hospitalization are examples of such confounding factors. It is not possible to delineate the effect of surgical exposure and hospitalization from anaesthetic exposure. Retrospective data is subject to imprecision or error. The cohorts represented in these studies were children who had anaesthesia and surgery two to three decades ago, there have been many advances in surgical approach and anaesthetic techniques, and hence results from previous treatment may not apply today. Neurocognitive outcome is difficult to study in children and because of the growing complexity in their neurocognitive development as they age. This warrants more types of psychometric tests to assess domains which were not applicable at a younger age, which is to say that more domains need to be tested. Adding to this problem is the fact that it is not known which domain is affected most by anaesthesia related neurotoxicity. Coarse scoring systems such as IQ or measures such as diagnosis of developmental delay may overlook any subtle effects confined to specific areas; however, more refined psychometric tests have an increased chance of finding at least one association purely by chance. Tests carried out at an early age will only uncover major neurological problems and psychometric tests carried out in young children are poor at predicting later outcome ${ }^{26,27}$.

Given the limitations inherent in retrospective studies, prospective randomized studies are clearly needed to clarify long-term cognitive effects of early anaesthetic exposure in humans. The main problem is one of confounding factors. The effects of anaesthesia cannot be dissociated from factors associated with anaesthesia, such as surgical trauma and pathology. Surgery is associated with other confounding factors such as humoral and inflammatory stress as well as metabolic, haemodynamic and respiratory events, which may all influence outcomes. Infants and children having surgery or diagnostic procedures are very likely to have pathology, which may influence neurobehavioural outcome. They may be septic, premature, have less parental interaction or have chromosomal abnormalities, all of which can also be associated with developmental delay and need for surgery.

Currently there are two large-scale studies underway that are trying to address the issue of anaesthetic neurotoxicity in children. One that will attempt to separate the effects of general anaesthesia from surgical procedure is the General Anaesthesia Study (GAS) ${ }^{28}$. This is a multi-centre randomised controlled trial involving 29 centres around the world. The primary objective of this study is to compare regional and general anaesthesia for effects on neurodevelopmental outcome and apnoea in infants requiring inguinal hernia repair. Six hundred infants below 60 weeks post-conception age are randomised to receive either general anaesthesia with sevoflurane or spinal anaesthesia without sedation. The follow-up period will be at 5 years, with evaluation performed at 2 years using the Bayley Scales for Infant Development-III and at 5 years using the Wechsler Preschool and Primary Scale of Intelligence-III and additional neuropsychological tests within NEPSY-II (A developmental NEuroPSYchological assessment). The expected date of completion is $2015 / 2016$. The other one is the PANDA (Pediatric Anaesthesia and Neurodevelopmental Assessment) study, which is another multi-centre study that involves eight US sites. This study proposes using a bidirectional epidemiological approach where a historical cohort exposed to a single general anaesthesia for inguinal hernia repair American Society of Anaesthesiologist (ASA) class 1 and 2 before 36 months of age is identified. The group will be followed up prospectively using neurocognitive testing between the ages of 6 and 10 years. This study is an attempt to reduce the genetic and environmental contributions to cognitive performance. The pilot study has been completed, which demonstrated feasibility of such an approach ${ }^{29}$.

Therefore, it is clear from preclinical data that anaesthetic agents are associated with neurotoxicity in developing animals ${ }^{30,31}$. However interpretation of clinical studies that have been completed to date is less clear-cut. This is due to the retrospective nature of the studies, the lack of specific information in terms of age, duration, and dose of anaesthetics, precise agents used, the variable outcome endpoints used and the way these outcomes were assessed. Many of the outcome measures were lacking in specificity and standardization in most cases. Any change in anaesthetic practice should be evidence based. The Anaesthetic and Life Support Drugs Committee of the U.S. Food and Drug Administration held a meeting in March 2011 and concluded that they acknowledge the compelling animal data that anaesthesia exposure is neurotoxic to the developing brain. However, there is still not enough data, especially in humans, to draw any firm conclusions.

\section{Conclusions}

In conclusion although there are some data suggesting a possible detrimental effect of anaesthesia on the developing brain in children, the evidence is best considered preliminary and inconclusive at this stage. However what we do know is that it is unethical to subject infants and children to surgery without the benefits of anaesthesia and analgesia. Parents should be counselled to 
not avoid necessary invasive procedures for fear of a currently ill-defined risk.

\section{Author contributions}

Clara KY Yu performed original literature search and draft both the manuscript and tables. Vivian Man Ying Yuen performed an independent literature search, and prepared tables. Gordon TC Wong prepared the manuscript and tables Michael G. Irwin conceived the idea and made critical revisions of the manuscript. All authors have read and are agreeable to the publication of the current article.

\section{Competing interests}

No competing interests were disclosed.

\section{Grant information}

The author(s) declared that no grants were involved in supporting this work.
1. Anand KJ, Hickey PR: Pain and its effects in the human neonate and fetus. N Engl J Med. 1987; 317(21): 1321-9.

PubMed Abstract | Publisher Full Text

2. Fitzgerald M, Millard C, McIntosh N: Cutaneous hypersensitivity following peripheral tissue damage in newborn infants and its reversal with topical anaesthesia. Pain. 1989; 39(1): 31-6.

PubMed Abstract | Publisher Full Text

3. Johnston CC, Stevens BJ: Experience in a neonatal intensive care unit affects pain response. Pediatrics. 1996; 98(5): 925-30.

PubMed Abstract

4. Taddio A, Katz J, llersich AL, et al.: Effect of neonatal circumcision on pain response during subsequent routine vaccination. Lancet. 1997; 349(9052) 599-603.

PubMed Abstract | Publisher Full Text

5. Jevtovic-Todorovic V, Hartman RE, Izumi Y, et al.: Early exposure to common anesthetic agents causes widespread neurodegeneration in the developing rat brain and persistent learning deficits. J Neurosci. 2003; 23(3): 876-82. PubMed Abstract

6. Ikonomidou C, Bosch F, Miksa M, et al:: Blockade of NMDA receptors and apoptotic neurodegeneration in the developing brain. Science. 1999; 283(5398): 70-4.

PubMed Abstract | Publisher Full Text

7. Oppenheim RW: Cell death during development of the nervous system. Annu Rev Neurosci. 1991; 14: 453-501. PubMed Abstract | Publisher Full Text

8. Kalkman CJ, Peelen L, Moons KG, et al: Behavior and development in children and age at the time of first anesthetic exposure. Anesthesiology. 2009; 110(4): $805-12$

PubMed Abstract | Publisher Full Text

9. DiMaggio C, Sun LS, Kakavouli A, et al.: A retrospective cohort study of the association of anesthesia and hernia repair surgery with behavioral and developmental disorders in young children. J Neurosurg Anesthesiol. 2009; 21(4): 286-91.

PubMed Abstract | Publisher Full Text | Free Full Text

10. Ing $\mathrm{C}$, DiMaggio $\mathrm{C}$, Whitehouse $\mathrm{A}$, et al.: Long-term differences in language and cognitive function after childhood exposure to anesthesia. Pediatrics. 2012; 130(3): e476-85.

PubMed Abstract | Publisher Full Text

11. Bartels M, Althoff RR, Boomsma DI: Anesthesia and cognitive performance in children: no evidence for a causal relationship. Twin Res Hum Genet. 2009; 12(3): 246-53.

PubMed Abstract | Publisher Full Text

12. Hansen TG, Pedersen JK, Henneberg SW, et al.: Academic performance in adolescence after inguinal hernia repair in infancy: a nationwide cohort study. Anesthesiology. 2011; 114(5): 1076-85. PubMed Abstract | Publisher Full Text

13. Wilder RT, Flick RP, Sprung J, et al.: Early exposure to anesthesia and learning disabilities in a population-based birth cohort. Anesthesiology. 2009; 110(4): 796-804.

PubMed Abstract | Publisher Full Text | Free Full Text

14. Flick RP, Katusic SK, Colligan RC, et al.: Cognitive and behavioral outcomes after early exposure to anesthesia and surgery. Pediatrics. 2011;128(5): e1053-61.

PubMed Abstract | Publisher Full Text | Free Full Text

15. Sprung J, Flick RP, Wilder RT, et al:: Anesthesia for cesarean delivery and learning disabilities in a population-based birth cohort. Anesthesiology. 2009; 111(2): 302-10.

PubMed Abstract | Publisher Full Text | Free Full Text
16. Sprung J, Flick RP, Katusic SK, et al.: Attention-deficit/hyperactivity disorder after early exposure to procedures requiring general anesthesia. Mayo Clin Proc. 2012; 87(2): 120-9.

PubMed Abstract | Publisher Full Text | Free Full Text

17. Eckenhoff JE: Relationship of anesthesia to postoperative personality changes in children. AMA Am J Dis Child. 1953; 86(5): 587-91. PubMed Abstract

18. Brambrink AM, Evers AS, Avidan MS, et al:: Isoflurane-induced neuroapoptosis in the neonatal rhesus macaque brain. Anesthesiology. 2010; 112(4): 834-41. PubMed Abstract | Publisher Full Text

19. Slikker W Jr, Zou X, Hotchkiss CE, et al:: Ketamine-induced neuronal cell death in the perinatal rhesus monkey. Toxicol Sci. 2007; 98(1): 145-58. PubMed Abstract | Publisher Full Text

20. Hemmings $\mathrm{HC}$ Jr, Akabas MH, Goldstein PA, et al.: Emerging molecular mechanisms of general anesthetic action. Trends Pharmacol Sci. 2005; 26(10): 503-10.

PubMed Abstract | Publisher Full Text

21. Hensch TK: Critical period regulation. Annu Rev Neurosci. 2004; 27: 549-79. PubMed Abstract | Publisher Full Text

22. Huttenlocher PR, Dabholkar AS: Regional differences in synaptogenesis in human cerebral cortex. J Comp Neurol. 1997; 387(2): 167-78. PubMed Abstract | Publisher Full Text

23. Sowell ER, Peterson BS, Thompson PM, et al.: Mapping cortical change across the human life span. Nat Neurosci. 2003; 6(3): 309-15. PubMed Abstract | Publisher Full Text

24. Rakic S, Zecevic N: Programmed cell death in the developing human telencephalon. Eur J Neurosci. 2000; 12(8): 2721-34. PubMed Abstract | Publisher Full Text

25. Flick RP, Wilder RT, Sprung J, et al: Anesthesia and cognitive performance in children: no evidence for a causal relationship. Are the conclusions justified by the data? Response to Bartels et al., 2009. Twin Res Hum Genet. 2009; 12(6): 611-2; discussion 613-4 PubMed Abstract | Publisher Full Text

26. Korkman M, Kemp SL, Kirk U: Effects of age on neurocognitive measures of children ages 5 to 12: a cross-sectional study on 800 children from the United States. Dev Neuropsychol. 2001; 20(1): 331-54. PubMed Abstract | Publisher Full Text

27. Hack M, Taylor HG, Drotar D, et al:: Poor predictive validity of the Bayley Scales of Infant Development for cognitive function of extremely low birth weight children at school age. Pediatrics. 2005; 116(2): 333-41. PubMed Abstract | Publisher Full Text

28. A Multi-site Randomized Controlled Trial Comparing Regional and General Anesthesia for Effects on Neurodevelopmental Outcome and Apnea in Infants (GAS). ClinicalTrials.gov Identifier: NCT00756600. Reference Source

29. Sun LS, Li G, DiMaggio CJ, et al: Feasibility and pilot study of the Pediatric Anesthesia NeuroDevelopment Assessment (PANDA) project. J Neurosurg Anesthesiol. 2012; 24(4): 382-8. PubMed Abstract | Publisher Full Text | Free Full Text

30. Kabra NS, Schmidt B, Roberts RS, et al.: Neurosensory impairment after surgical closure of patent ductus arteriosus in extremely low birth weight infants: results from the Trial of Indomethacin Prophylaxis in Preterms. $J$ Pediatr. 2007; 150(3): 229-34, 234.e1. PubMed Abstract | Publisher Full Text

31. Tobiansky R, Lui K, Roberts S, et al:: Neurodevelopmental outcome in very low birthweight infants with necrotizing enterocolitis requiring surgery. $J$ Paediat Child Health. 1995; 31(3): 233-6.

PubMed Abstract | Publisher Full Text 


\section{Open Peer Review}

\section{Current Peer Review Status:}

\section{Version 1}

Reviewer Report 07 August 2013

https://doi.org/10.5256/f1000research.1523.r1332

(C) 2013 Luginbuehl I. This is an open access peer review report distributed under the terms of the Creative Commons Attribution License, which permits unrestricted use, distribution, and reproduction in any medium, provided the original work is properly cited.

\section{Igor Luginbuehl}

University of Toronto, Toronto, Canada

This is a very complex topic of significant importance and interest not only to anesthesiologists, but also to parents and, of course, the patients. A lot of research has been done in that regard, but we are still awaiting a definite answer, which will most likely take a long time.

Competing Interests: No competing interests were disclosed.

I confirm that I have read this submission and believe that I have an appropriate level of expertise to confirm that it is of an acceptable scientific standard.

Reviewer Report 06 August 2013

https://doi.org/10.5256/f1000research.1523.r1334

(C) 2013 Ing C. This is an open access peer review report distributed under the terms of the Creative Commons Attribution License, which permits unrestricted use, distribution, and reproduction in any medium, provided the original work is properly cited.

\section{Caleb Ing}

Pediatric Anesthesia, Columbia University Medical Centre, New York, 10032, USA

This paper presents a nice summary of the clinical studies that have been performed to evaluate the long-term effects of anesthetic exposure in young children. However, in order to improve the accuracy of the paper, there were a few corrections to point out:

The Western Australian Pregnancy Cohort Study (Raine) consisted of 2868 children of which 2608 were evaluated in the cited study, with 321 who had surgical procedures before age 3 years.

Table 2: In the Raine Cohort, the study group was composed of 321 children exposed to anesthesia and 2287 children who were unexposed. The number of children tested for each 
outcome however varied by individual outcome and also varied during the evaluation of single and multiple anesthetic exposures. While several studies only found a difference in cognitive outcomes after multiple anesthetic exposures, evaluation of the Raine cohort found differences even after a single exposure. This may be due to the use of more sensitive directly assessed neurocognitive measures in this cohort.

Also as a clarification, in this study, the age of neurological assessment for all children was at age 10.

Competing Interests: No competing interests were disclosed.

I confirm that I have read this submission and believe that I have an appropriate level of expertise to confirm that it is of an acceptable scientific standard.

The benefits of publishing with F1000Research:

- Your article is published within days, with no editorial bias

- You can publish traditional articles, null/negative results, case reports, data notes and more

- The peer review process is transparent and collaborative

- Your article is indexed in PubMed after passing peer review

- Dedicated customer support at every stage

For pre-submission enquiries, contact research@f1000.com 